\title{
The nostalgic landscape of Miami in Susanna Daniel's Stiltsville
}

\begin{abstract}
The article examines the nostalgic landscape of Miami depicted in Susanna Daniel's debut novel Stiltsville (2010). The setting of the novel is the actual community named in the title of the book and it refers to a group of houses built on pilings about a mile offshore in Biscayne Bay. The analysis proceeds according to methodology presented by the literary theorist Hana Wirth-Nesher in her article titled "Impartial Maps: Reading and Writing Cities", published in Handbook of Urban Studies (2001), in which she identifies four aspects of cityscape in the representation of the city in narrative: the built, the 'natural', the human, and the verbal. The paper discusses the nostalgic construction of the past in the novel. Nostalgic notions of preserving the past have been linked with the concepts of cultural heritage and the preservation movement.
\end{abstract}

Keywords: Stiltsville, Florida, marine environment, Hurricane Andrew, landscape, nostalgia.

\section{Introduction}

The article examines the nostalgic cityscape of Miami depicted in Susanna Daniel's debut novel Stiltsville, published in 2010 by HarperCollins Publishers. The author, who was born and spent most of her childhood in Miami, Florida, graduated from Columbia University and the University of Iowa Writers' Workshop. Her first novel, Stiltsville, was awarded the PEN/Bingham prize for best debut work published in 2010, and it was also placed on the 2011 Summer Reading List selection by Oprah.com. The setting is the actual community named in the title of the book and it refers to a group of houses built on pilings about a mile offshore in Biscayne Bay in Florida. Scott Eyman in his review published in The Palm Beach Post (2010) writes: "The most exotic thing about the novel is the setting". The author grew up in Miami's Coral Gables and her family had a house in Stiltsville, which Daniel considered to be an excellent setting for a novel. Her family shared the stilt house and paid its maintenance costs together with other families until it was destroyed by Hurricane Andrew. There are biographical traces in Daniel's construction of the main character. "Frances is my mother in a lot of ways; I wrote Frances to honor my mother", says Daniel (Eyman 2010). In an interview with Laura Valeri, Susanna Daniel talks about the inspiration for her novel:

1 Address for correspondence: Institute of English Studies, University of Rzeszów, al. Mjr. Kopisto 2B, 35-315 Rzeszów, Poland. E-mail: mmart@univ.rzeszow.pl 
"I wanted to parallel the story of a long marriage to the history of Stiltsville, the place, and the coming-of-age of the city where I grew up". The author emphasizes the significance of changes by saying: "Stiltsville is both relegated to history and also still in existence, in a different form-like a lot of families, including mine" (Valeri 2011).

The book depicts the long marriage of Dennis and Frances DuVal, but at the same time, it focuses on the moments in which the family experienced unexpected changes. The story is narrated by the main character, 26-year old Frances Ellerby, who moves to Miami from Decatur, Georgia, close to Atlanta. The people Frances spends most of her time with in Miami are her husband Dennis DuVal, his sister Betty, and her friend Marse Heiger. The novel follows Frances through her courtship with Dennis, their marriage and raising their only child, Margo. The story relies on the narrator's memory and recollections of particular periods and events from the past which are vital for Frances. The novel spans 25 years and is divided into chapters corresponding to the chronological time periods: 1969, 1970, 1976, 1982, 1990, 1992, 1993. The first chapter, concerning events in 1969, begins when Frances makes her first-ever visit to Miami to attend the wedding of a college girlfriend. At the beginning of the novel Frances appears not to fit sultry South Florida, as for a young girl from Georgia, Miami seems decadent. Eventually, she leaves behind her old life and a boring bank job in Atlanta and starts a new life in Miami which focuses on Stiltsville. As time passes, numerous changes occur affecting both Frances's family and the city of Miami until Hurricane Andrew destroys their stilt house.

The present analysis of the novel is constructed according to methodology presented by the literary theorist Hana Wirth-Nesher in her article titled "Impartial Maps: Reading and Writing Cities", published in Handbook of Urban Studies (2001), in which she identifies four aspects of cityscape in the representation of the city in narrative: the human, the built, the 'natural', and the verbal. The built environment depicts the city's architecture, streets, squares, and other man-made objects. The 'natural' environment refers to the incorporation of nature in the metropolitan imagination: landscapes, parks, plants, even weather. The human environment does not refer to the main characters of the novel but rather to those human features that define the setting, such as city-dwellers, tourists and shop owners. The verbal environment describes the language of the novel and refers to the written names of places and streets, the language of notices and advertisements as well as the spoken language the characters use in the narrative (Wirth-Nesher 2001: 54). The purpose of this paper is not only an examination of the four environments of Miami's cityscape that are featured in the novel Stiltsville but also discussion of the narrator's nostalgic construction of the past, an example of the nostalgic notions that have been linked with the cultural heritage of South Florida.

The concept of nostalgia, coined in 1688 by a Swiss physician, Johannes Hofer, was primarily associated with homesickness (Tierney 2013). Later, the term started to express a longing for the past and acquired a connotation of sentimentality. Fred Davis defined nostalgia in the following words: "a form of sentimental yearning for any object, event, or place in the past or a positively formed evocation of the past" (1979: 18). Looking back at the past and reconstructing it provides a positive context for present life; however, a nostalgic vision of the past is not the same as the actual 
past. It is a selection of events from the past rather than a true historical account. Nostalgic narratives are embedded in a social context and comment on how memory works. American heritage historian and geographer David Lowenthal claims that while recollecting the past we transform it with the aim of preserving it; however, the actual past was not like our memories about it because "Nostalgia evokes better-off as well as better times" (2015: 41). In our own memories, we discard events from the past that are unwanted in contemporary times and present an idealized version of the past. You cannot retrieve the past because you "can return to a place, but never to a past" (Lowenthal 2015: 50).

Political scholar Kimberly Smith (2000: 509) claims that nostalgia is a cognitive process in which one not only memorizes certain things but adopts a particular attitude towards things to romanticize the past. Literary theorist Svetlana Boym describes 'reflective nostalgia' as making people contemplate the passage of time and their identity by reflecting upon the value of the past for present purposes. Reflective nostalgia refers to "individual and cultural memory" (2001: 41) which emphasizes the imperfect process of remembrance. It accepts the fact that some events belong to the past but cherishes emotions evoked by the experience of recollecting the past. The acknowledgment of the irretrievability of the past creates a space in which memory selects events for our emotional pleasure, and the fact that experience belongs to the past makes us enjoy it in the present.

As sociologist Janelle Wilson notices, the experience of nostalgia helps people to infuse the past with new meaning that is significant in the present (2005: 23). Past experiences may be remade, rediscovered or even renewed; however, a nostalgic image may be blurry because nostalgia mythologizes the past. Past recollections concern specific times and places, but even after returning to a particular place we find that nothing has stayed the same as numerous changes have occurred. What matters is not that the past is recreated but how the past is reconstructed in re-telling. The research conducted by Sedikides, et al. revealed that nostalgia may facilitate continuity between past and present, and in this way "use positive perceptions about the past to bolster a sense of continuity and meaning in one's life" (2008: 306). Reverting to the past is seen as a way of compensation for the threatening changes occurring in the modern world.

The notion of nostalgia has found recognition in the field of urban studies and it has been associated with the creation of remembrance museums, heritage preservation parks and with concepts of the recovery, restoration, and maintenance of traditions. Urbanization caused the destruction of numerous historical landmarks, which made Americans feel a nostalgic sense of loss. In the 1960s the federal government began to fund projects aimed at the preservation of historic heritage and architects turned to history and the celebration of vernacular housing (Zukin 1982: 75). Literary theorist Linda Hutcheon claims that nostalgia is connected with the manifestation of vernacular-revival architecture and preservation activity (2002: 177). Historian Alison Isenberg (2004) links nostalgia with urban revitalization policies, as nostalgic themes became a part of landscape planning and urban aesthetics. The movement for the preservation of American historic heritage was stimulated by nostalgia as well as its tourist potential. According to Lowenthal, the preservation movement concerns not only single pieces of architecture but larger areas. "Preservation 
reaches beyond single structures to embrace neighborhoods and entire towns" (2015: 421). Every American state has its own unique culture that may be the object of nostalgic preservation and the state of Florida even has a term - Floridiana - which applies to its characteristic artifacts, historical heritage, geography, architecture or folklore. Merriam Webster Dictionary defines 'Floridiana' as "material (as documents, anecdotes, or artifacts) distinctively bearing on or characteristic of Florida or its people or culture". The cityscape of Miami is a kind of palimpsest landscape combining historical, architectural and cultural features of the city with the geographic environment of Floridiana, and the Stiltsville enclave is a symbolic landscape of Miami, which synthesizes its urban and marine environments.

\section{Cityscape of Stiltsville: the built environment}

The built environment of the novel Stiltsville represents both the existing artifacts of Floridiana and structures invented by the author. The former "derive their significance from both the text in which they are represented and the existing repertoire of city tropes in the arts and literature" (Wirth-Nesher 2001: 55). Stiltsville has been featured as the setting of other novels: Skin Tight (1989) by Carl Hiaasen; Done Deal (1993) by Les Standiford; Dearly Devoted Dexter (2005) which is the second novel in the crime series about Dexter written by Jeff Lindsay; and Sea Creatures (2013) by Susanna Daniel. Although the novel Stiltsville does not make any references to the mentioned books, the fact that the houses on piles in Biscayne Bay inspire so many writers proves the prominence of the enclave.

The fictional world of Daniel is set in the physical landscape of Miami. The narrative encompasses two Miami spaces: the mainland and offshore Stiltsville, which is located five miles from the city downtown. Despite this distance, Stiltsville is considered part of the Miami cityscape, so part of Floridiana as well. The enclave is both included in the urban metropolitan environment and excluded from it, as it is only accessible by boat. This closed community, resembling an island, developed as a kind of weekend paradise and provides a sense of intimacy for its residents. The separation between the public and the private is maintained because the characters spend weekdays in Miami whereas the stilt house serves as a private enclave and a refuge from urban life reserved for weekends. The narrator calls the stilt house "our little island, our weekend oasis" (75). The city of Miami plays an important role in Frances's life; however, meaningful events happen at Stiltsville. The narrator selects only particular years for the story and presents them chronologically. It is not an actual description of the past but a selection of key experiences which are always connected with the stilt house. As Lowenthal puts it, "Heritage is scolded for swerving from the true past-selecting, altering, inventing" (2015: 112).

Wirth-Nesher states that the novelist incorporates some aspects of real cityscape into fictive reconstruction by providing the names of streets, places, and landmarks. In this way the author enables the reader to place the character in the real setting and to recognize the significance of particular localities as a "vocabulary of cityscape elements" arrives at "universal determinants of legibility" (2001: 52). At the beginning of the novel, Frances's friend Marse takes her on a sightseeing 
boat trip. In this way Daniel affectionately evokes the Miami landmarks, starting with Freedom Tower in the city's downtown. Then, Marse points to the bridge connecting the downtown to Key Biscayne - the area including the neighborhood of Stiltsville. Marse presents other parts of the city, starting from the southwest: The Everglades, Turkey Point, Coral Gables, Coconut Grove, and to the east: the Cape Florida Lighthouse located at the tip of Key Biscayne. The lighthouse, built in 1825, is the oldest building in south Florida. Another architectural spot worth visiting mentioned further in the first chapter is Vizcaya - a villa in the Renaissance style surrounded by elaborate gardens and located on the bay in Coconut Grove. The narrator in her nostalgic memories presents the historic heritage of the city which corresponds with Linda Hutcheon's theory linking nostalgia with preservation activity (2002). As the story develops, Frances seems constantly fascinated with the city of Miami: "Because a century ago, swampland enveloped this shoreline, before developers drained it and built a city from the bog. Because our piece of Florida was invented, not discovered" (148). It is Dennis's parents who own the stilt house, built in 1945 by Dennis's father, Grady, who adopted the idea of a local fisherman named "Crawfish" Eddie Walker (21). It is a direct reference to the real history of Stiltsville which was started in the days of prohibition by "Crawfish" who sold bait and beer at his stilt house, so the author uses elements of the historical account of Floridiana heritage for her fictional story. Frances describes her first sight of Stiltsville, which consisted of 14 houses elevated above the water on pilings, in the following way: "They stood on cement pillars, flanking a dark channel along the rim of the bay as if guarding it from the open ocean" (2). Theirs is a redpainted house with white shutters which is later referred to in the story as the "stilt house". This place turns out to be a special location where the characters always return when something significant happens in their lives. It is the stilt house where Frances is introduced to Dennis DuVal and it is also the place where he proposes to her. It seems that the romantic scenery of the house built on the water makes an ideal setting for events that are meaningful for Frances. Nina Sankovitch (2011) in a review of the novel published in The Huffington Post writes: "Frances is enchanted by the neighborhood hovering over water, and falls in love with the rhythm and beauty of Southern Florida". Even her mother remarks during one of her winter visits to see Frances: "Miami suits you" (253).

Frances emphasizes in her narration that despite the changes that occur in the life of the family, Stiltsville continues to play a prominent role for all of the family members, including her daughter Margo. She takes up a number of activities at school to gain extra credits for her university application. One of the activities she practices is competitive sailing, but she gives it up saying that "the regattas monopolized all her weekends" (153), so she had no time for visiting Stiltsville. When Margo transfers from the University of Miami to the University of Florida, she spends her last night with the family at Stiltsville. It is also at the stilt house where Margo expresses a request to move out of the dorms into an apartment complex off campus. It seems that all the decisions that are important for the family are discussed and made at Stiltsville. The family members are aware that their custom of staying at the stilt house will have to end soon because the state of Florida has declared Biscayne Bay a national park, which meant that private ownership of the stilt houses was going to be brought to an end. Again, the fictional narrative refers to real state 
regulations. Even though the family still keeps the place they are aware of how much they are going to miss the house after losing it. Their life is constantly changing but the loss of Stiltsville induces a complete change of their lifestyle. When Margo leaves for university, Frances suddenly realizes she has extra time to occupy, which is difficult because Frances "wasn't used to spending time outside other than at Stiltsville" (164). The narrator makes nostalgic recollections to compensate for violent changes occurring in her life.

As sociology professor Jan Willen Duyvendak puts it in The Politics of Home: Belonging and Nostalgia in Western Europe and the United States, a home may be a non-material place or its image linked to a concrete manifestation of the home in the past (2011: 37). Pam Cook states that "nostalgia is predicated on a dialectic between longing for something idealized that has been lost, and an acknowledgment that this idealized something can never be retrieved in actuality, and can only be accessed through images" (2005: 3). While reminiscing on the past, Frances not only makes recollections of the actual past but also depicts a nostalgic vision of home by presenting its images, like the one depicting what Stiltsville would look like from the view of a plane: “...the houses perched on stilts in the bay would dissolve in the blurring of waves and sky" (73). Another image Frances produces is connected with the potential destruction of the stilt house by the hurricane, which is immediately connected with the concept of the family:

Maybe we would anchor where our stilt house had stood and dive the spot like any wreck, searching for bed frames, shutters, shoes. We would feel loss and lost, and I would realize once again: this is what it means to be part of a family. There are no maps and the territory is continually changing (117).

After having learned the house has been destroyed by Hurricane Andrew in 1992, Frances narrates: "I imagined pieces of our stilt house stranded there-shutters or dock planks or even the hurricane tracking map that hung in the kitchen, its little red and blue magnets scattered across the bay floor" (229). Frances expresses what the house meant to her: "It was a treasure, this sense of isolation. How would we achieve it, if we didn't rebuild?" (231). The images of the house produced by the narrator correspond with Duyvendak's concept of defining nostalgia as not only longing for a place but mourning over changes that have occurred in that particular place. You cannot truly return to that place because it exists mostly in your imagination (2011: 24).

Duyvendak connects the notion of place with the activity of home-making as the necessity for the place to be transformed into a home. He claims that the building itself has no real 'home' value if there are no feelings attached or if it is not connected with activities occurring in that particular place. "Home is more the result of home-making than the effect of the place itself" (2011: 37). When Frances wants to show Margo's husband, Stuart, what the stilt house looked like, she searches through the old photographs, but it turns out that there is actually no record showing the whole house. Instead, they can see Margo on the dock, Dennis with a railing behind, or Frances in the doorway. Surprised, Frances narrates: "There was no photo of the house the way I remember 
it: from a distance, wholly intact. I did not understand, taking those pictures, that history must be collected while the subject exists" (243). Actually, the pictures reflect what the stilt house meant to them - a family place. The house was significant only when family members occupied it. Frances recollects the good old days when a physical therapist comes to help Dennis with exercises that would slow the degeneration of his muscles. When they are doing some exercises in the water, Frances nostalgizes about the family time at the stilt house when Margo was a little girl and Dennis used to teach her to swim. Once, when Dennis is strong enough, Frances takes him and Margo on the boat at night and they anchor in the spot where their stilt house stood. They are eating crabs and looking at the downtown skyline like they used to in the past. Although Frances misses Stiltsville, she realizes that even if their stilt house had not been destroyed, they would not be able to use it because of Dennis's illness. "It had collapsed before becoming a sad, abandoned treasure" (287). The narrator identifies with the house even when it no longer exists which corresponds with Svetlana Boym's concept of 'reflective nostalgia' (2001).

Duyvendak states that there are places that have the meaning of 'home' as a fixed physical space, which is significant because it gives people a sense of belonging and identity. This does not mean that individuals are fixed in place but rather that the place has a particular value for the individual (2011: 8). Frances identifies with Stiltsville but in a broader context she identifies with the whole city of Miami: "Miami is the only place in this country where Stiltsville could exist, and for a while I had the good fortune of spending time there" (72). After Dennis's death, Frances moves to Asheville, North Carolina where in the past they both spent a weekend hiking and watching street musicians. She narrates: "When I think about Miami, it is as if all I loved about the place no longer exists" (303). She means Dennis and the stilt house.

According to Lowenthal, the heritage and preservation movement may reflect nostalgia for the lost community (2015: 6). The coastal environment of Florida provides numerous obstacles to the preservation of the houses which are threatened by hurricanes and surrounded by saltwater. The tropical storms enumerated in the narrative are part of the actual history of Florida which is frequently devastated by their disastrous force. After Hurricane Andrew in 1992, the Stiltsville community shrank substantially and only seven structures remained. This fact is true for both the fictional landscape of the novel and the real account of Miami's history. Those seven houses have also survived the most recent Hurricane Irma (2017) relatively unscathed; just one of the houses needed roof repairs and some dock and railing were damaged (Rabin 2017). Daniel was not able to acknowledge this fact in her book which was published in 2010, seven years before Hurricane Irma.

\section{Cityscape of Stiltsville: the 'natural' environment}

The 'natural' cityscape of the novel is focused on the coastal and marine environment of Miami which determines the characters' routine of celebrating weekends. They develop a habit of staying at Stiltsville together with Dennis's parents, his sister Betty, and occasionally they are joined by their friend Marse. They spend time sailing, swimming, walking on the sandbar between the stilt houses which they call the 'flats' and looking for starfish, sea worms and fire coral. Then they eat fish, 
lobsters, or other sea creatures they have caught themselves. Daniel also mentions clubs connected with the marine environment of Miami, like the Biscayne Bay Yacht Club which Dennis joins in 1976 and the Coconut Grove Sailing Club where Betty teaches sailing lessons. Duyvendak claims that the choice of home is often closely connected with the choice of lifestyle because the place known as home and its surroundings enable the individual to realize his or her passion, e.g. clubbing, sailing (10). The stilt house definitely assumes the meaning of 'home' to Frances, who becomes totally absorbed with her new lifestyle and totally removed from her previous life in Georgia.

The literary depiction of the stilt house evokes the image of the marine environment. Frances describes the house in the following words:

The main room of the stilt house was paneled with wood and stocked with old appliances and a shabby wicker sofa with turquoise vinyl cushions... The kitchen and the living area shared one open space, with two doors that opened onto the west and north porches. This design gave the house an inside-out quality, like the interior of a cabana or, I imagined, a yacht (12).

A decorative rope on the counter, a stack of fishing and boating magazines on a coffee table, and a huge marlin placed above the kitchen sink added touches of the marine environment to the interior of the house. Moreover, one of the bedrooms had a special type of furniture, namely, two bunk beds. The purpose of the downstairs' area was described in France's narration as "existing only to elevate the second floor away from the water" (13). The second story of the house had a veranda with a white wooden railing, but the first story had no railing so inhabitants or visitors to the house could simply jump directly from it into the water. A nostalgic look at the house idealizes it with the spirit of coziness and togetherness. The depiction evokes a great deal of sentimentality which corresponds with Fred Davis's definition of nostalgia (1979).

The characters enjoy the benefits of the coastal environment but at the same time show respect for its fauna and flora and caution with regard to its dangers. The reader can see how seriously Dennis treats the marine environment in the way he spends his time with his daughter at the stilt house. They study together survival tactics, discuss what to do when lost at sea, how to recognize which fish are poisonous, how to check the wind. When they learn that an electric eel lives in a bowl under the dock of the house, they seem to be proud of the fact that this wild creature chose this particular house for its habitat. Their intention is not to kill the eel but to catch it and find it a new home in a reef cave. However, during one of the summer weekends Marse's cousin dives down beneath the dock with a machete and chops off the electric eel's head. Afterward, Dennis tells Marse that her family is not welcome anymore. This event clearly proves that a wild sea creature living in the proximity of the stilt house was seen as a permanent neighbor for the house residents and killing it meant a betrayal of trust for Dennis. The eel belonged to the house and the family identified with it as they identified with the house. Killing the eel was a negative change in the stability of the house and its ideal surroundings. 
Frances evokes nostalgic memories connected with nice tropical weather by describing what spring and summer meant to her. The South Floridian spring is depicted in the following words: "bright warm days and few mosquitoes, and nights as crisp as seventy degrees" (54). Then, she refers to summer in the subtropics: "it was beautiful, clear, and sunny until mid-afternoon, then rained heavily for an hour, then the clouds cleared and the sun came out again" (255). She stresses a sort of temporality of bad weather which is always likely to change for the better.

Geographer Harm de Blij in his book The Power of Place: Geography, Destiny and Globalization's Rough Landscape, elaborates on the "geography of jeopardy" and tries to answer the question of why many Americans build their second homes along coastlines vulnerable to hurricanes. He argues that danger "forms a significant factor in the composite power of place" (2009: 108), and continues: "the power of place manifests itself in continua of opportunity and risk, advantage and privation" (2009: 136). A dangerous aspect of the marine and coastal environment of Florida is the stormy weather. At the opening of the novel, Frances asks: "How much weather could the house withstand?". This quality of living in the stilt house is reflected by the hurricane tracking map with tiny magnets indicating weather warnings. Frances narrates: "On land, one looks toward the ocean to predict whether the storm is coming. From the ocean, one looks to the horizon" (25). Frances describes the destructive force of the hurricanes which had hit Stiltsville over the years. In 1960 Hurricane Donna leveled all but the six of the houses. Many residents rebuilt their houses in a new cottage-style and more solidly designed. Unfortunately, after Hurricane Betsy in 1965 only 14 structures were left. Other tropical storms mentioned in the narrative are Hurricane Agnes which hit Florida in 1972, Hurricane David which in 1979 tore part of the roof from the stilt house and Hurricane Hugo which struck in 1989.

The narrator recollects the past with concern about two dimensions which cannot be separated: specific time and space. In the words of Christine Sprengler: "nostalgia retained its spatial dimension" (2009: 15). The stilt house from the novel survived Hurricanes Betsy, Agnes, and Hugo. Then, in 1992, Hurricane Andrew came. When the National Hurricane Center issued a storm warning for Dade County, Frances "imagined the stilt house without its roof, the dock splintered" (217). When the storm started, she knew that "there would be nothing left" (217). After the hurricane, the city of Coral Gables closed the canal to private traffic and they did not know the fate of Stiltsville. Dennis said: "If the stilt house is gone, I don't want to rebuild". Many people lost their houses in the hurricane so had to depend on the Red Cross, which prepared tents for the newly homeless. Frances narrates: "Our neighborhood felt to me like an island refuge - like Stiltsville, in a way - isolated from a continent of disaster and disaster relief" (225). Finally, they were able to get to Stiltsville to learn the fate of their house and check the hurricane damage. Frances narrates this experience: "Our stilt house had stood seventh from the right. We counted under our breath: one, two, three houses remained, all west of where ours had been. The house was gone. From a distance, the breach seemed neat and deliberate, as if God had plucked our stilt house from its stem" (228). Nostalgia is used as a tool for representing a 'paradise lost' which existed not only in the past but at a specific time in the past. Their stilt house existed till 1992; then it became a 'paradise lost'. 
The stilt house becomes the metaphor for happiness that was lost instantly in a storm. The destruction of the house by a hurricane makes it the material for nostalgia and foreshadows Frances's husband's death which occurs shortly afterward. Roberta Rubenstein in Home Matters: Longing and Belonging, Nostalgia and Mourning in Women's Fiction, defines nostalgia as "a kind of haunted longing: figures of earlier relationships and the places with which they are associated" (2011: 5). It is not only longing for a significant place but for a figure strongly associated with the place. Frances constructs her identity in relation to the stilt house and her husband.

\section{Cityscape of Stiltsville: the human environment}

The human cityscape of the novel Stiltsville consists mainly of white people and Hispanics, particularly Cubans. The most important character not belonging to the family is Frances's friend -Marse. They both meet frequently and spend time talking about Marse's acquaintances. It seems that in certain Miami circles people have known each other's families for decades. "In so many ways, Miami was a small town" (195). However, it is mostly whites that they talk about and spend time with, which does not mean that they are oblivious to the Hispanic presence in the city. Frances meets some Cuban ladies at the YMCA gym in Miami, but no Cuban is ever a close acquaintance of her family: "Miami was more than half Cuban at this point, and yet I could count the Cuban couples in our social circle on one hand" (239). This situation may be explained by American architectural historian Gwendolyn Wright who writes in Modern Architectures in History: "American cities were segregating commercial and residential environments, yet urban social life retained a dynamic creole mixture" (2008: 37). The characters of the novel rarely contact Hispanics in their private lives but frequently meet them in their public lives as Latinx, particularly Cubans, combine a permanent and constantly growing fixture of Miami's cityscape.

The Cuban landscape of Miami is introduced by the city's landmark - Freedom Tower. Frances mentions that from the stilt house it was possible to distinguish the shape of the lighthouse or Freedom Tower. Then, she makes a reflection. "Considering the blue expanse of ocean in my vision and the thousands of glassy wavelets and the fathoms of veiled blond seafloor, I would have thought I could see to Cuba" (14). Although Frances's life in Miami is in a peculiar way almost entirely isolated from contacts with any members of the Cuban diaspora, she realizes the strangeness of this situation. She mentions Freedom Tower and immediately Cuba comes to her mind because that particular construction serves as the reception center for Cuban refugees. Another Hispanic accent occurs in the chapter narrating events from 1970 when Frances sees young girls wearing quinceañera outfits posing for photographs at the Spanish-style arches in Coral Gables. There is also a Hispanic character of Lola - an Ecuadorian therapist who helps Dennis when he is diagnosed with ALS. The Cuban presence in the city is shown when Frances starts a sort of flirtatious relationship with her tennis coach Jack. They go to the beach together and next to their spot there is a Cuban family having a picnic. Again, the Cubans are in the background of events and do not play any role in the activities performed by Frances. The novel pictures an undisturbed relationship between the whites and Hispanics. Both groups live close to each other in their isolated 
worlds but when they occasionally meet, harmony is maintained. The Cubans, although largely represented in the city, do not induce violent changes in Miami's landscape. Unlike them, the Africans do.

The African component of Miami's ethnic mosaic is introduced in the novel with the dramatic events that happened in 1980, following the so-called McDuffie case. Arthur McDuffie was a black insurance agent who was fatally beaten by Dade County police officers. The all-white jury in the McDuffie case acquitted the accused officers and the verdict caused riots in three Miami neighborhoods inhabited by African Americans. In the interview with Valeri, Daniel says: "When you live in a place like Miami, there's no separating the drama of family life from the drama of their surroundings" (Valeri 2011). Frances experiences the riots, but they do not touch her directly as she observes the events from afar - from the stilt house: "From Stiltsville, we could see smoke rising over the city, and when we got home, South Bayshore was a ghost town" (145).

The human environment of the novel, as well as the city itself, begins to change. Frances mentions in her narration that due to the changing demographics of the city many Miami dwellers start to move north, as do the Suttons who owned the stilt house directly west of Frances's house. They transfer their land lease and sell their house to a man who differs from other Stiltsville occupants as he does not treat the house as weekend accommodation but lives on the bay full-time and employs runners to bring food to him. His stay becomes so permanent that he does not even have a boat tied to his dock, which seems unwise considering emergency situations. Frances realizes that the city is changing but at the same time those changes do not affect her family which feels in a way insulated by the circles they move in. In his book Ethics and Nostalgia in the Contemporary Novel, John J. Sue writes about the prominence of place as "a response to a global shift in how individuals relate to the locations they inhabit" (2005: 20). The human environment of the novel implies changes connected with people's mobility and the narrative does not suggest temporality but rather the permanent character of those transformations. Frances is not touched directly by the social and urban transformations of Miami's cityscape because she finds comfort and safety in her magical place which is Stiltsville. In this context, the stilt house serves as protection against changes occurring in the human environment. Frances in her nostalgic memories recollects both the permanent routines of Stiltsville weekends and the times of meaningful changes, which she was able to stand due to the comforting refuge the house provided.

\section{Cityscape of Stiltsville: the verbal environment}

The verbal environment refers to both the written and spoken language of the novel. According to Wirth-Nesher the names of the cities themselves "signify beyond their geographical referent" (2001: 56). The written language of the novel makes use of narrative cartography to introduce the tropicalism of the places e.g. Coral Gables or Coconut Grove. Moreover, the Caribbean aspects of the city's charm are depicted by the names of trees and plants: banyans, mangroves, oranges, allamanda bushes, gumbo-limbo trees, and palms. The marine environment of Florida is evoked not only by flora but also fauna: pelicans, manatees, stone crabs, alligators, starfish, sea urchins, coral, 
sand dollars, electric eels and numerous types of shark: tiger, nurse, hammerheads, blacktip, bull, lemon. The seascape is clearly suggested by the names of restaurants: Fisheating Creek Inn, Diner Key Marina, Hungry Sailor.

The spoken language of the novel stresses the senses. John Urry in his article "City Life and the Senses" elaborates on the "sensuous geography" used to depict how the senses contribute to people's orientation in space and their appreciation of their environment. The senses are connected with visuality which provides an encounter with the environment and "sense of the surrounding townscape" (2003: 389-393). Frances affectionately describes the tropicality of Miami and emphasizes the sense of smell "I loved...smell the rotting sweetness of a ripening mango tree". She continues by stressing the visual aspect of the tropical environment: "I loved the limestone and the coral rock, the fountains and the ocean and the winding blue canals. I loved the giant banyans and the dense wet mangroves and gumbo-limbo trees and the many-sized, many-shaped palms" (72). When Frances gives birth to a baby daughter, she names her Margo because she feels that this name sounds south Floridian and tropical at the same time. The visuality aspect of the environment is mentioned during one of Margo's visits home from the university, which occurs on Independence Day. The family goes to the stilt house to "to watch fireworks over the skyline" (171) which suggests that the experience of watching the show is better at Stiltsville than from the Miami mainland. The visual aspect of the marine environment is emphasized by the use of colors: "the blue of the sky was rich and dense" (12), "the blue expanse of ocean in my vision" (14). Dark colors stress the dramatism of the night the hurricane hit: "Between flashes of lightning, the sky was purple-black and inky" (243).

The language of the cityscape clearly shows that the characters live in a city with a substantial Hispanic population which is made up mostly of Cubans. The exemplary situation occurs when Frances visits Dennis at his apartment and he goes out to buy limes at the mini market on the corner. Dennis calls the shop "bodega" which signifies that it specializes in Hispanic groceries. During his absence, Frances admires the sunset from the balcony and she sees two Cuban men standing at the entrance to the café and talking in Spanish. The Hispanic cityscape is visible in the food names mentioned in the narration. On one occasion Frances goes with her tennis coach to a Cuban restaurant in Little Havana and has a Cuban meal and drinks café con leche. Another time Frances takes Margo to a Mexican restaurant in Coconut Grove where they have tortilla chips, salsa, and enchiladas.

The narration introduces the reader to Miami's Hispanics by presenting their Spanish-sounding names, e.g. Margo's teacher of English is named Mr. Lopez, and her social studies teacher is Mrs. Gonzalez. When Margo and her newly-wed husband, Stuart, are looking for a house to buy, they visit the one belonging to Ms. Penny Morales who speaks with a heavy accent suggesting her Cuban roots. On another occasion, Frances mentions: "I loved to eavesdrop on the loud conversations of the ladies at the deli counter, ferreting out select phrases using the lazy Spanish I'd acquired over the years" (72). It became a sort of trend in certain Miami circles to drop some Spanish into casual conversation, but not too much, in order to avoid a discussion with the Hispanic housekeeper. 
Frances exemplifies this with a situation when Margo thanks to her friend's mother for inviting her to a birthday party. The woman welcomes Margo and says: "Qué linda". The verbal environment of the novel exemplified by the characters' dialogues and their dialect suggests ethnic subdivisions of the city. Spanish-speaking residents of the city are in the background of events that happen in Frances' life and they never visit Stiltsville. The verbal aspect of the cityscape marks some aspects of Miami's social hierarchy, as certain Miami circles are reserved only for Englishspeaking whites.

\section{Conclusion}

The novel portrays both Frances's marriage and the Stiltsville community, which is as old as the city of Miami and constitutes architecturally a significant example of Floridiana. The novel allows the readers to experience the marine environment of South Florida and the best it has to offer: the sky, the water, the boating, and fishing. The stilt houses represent an environmental sensibility and how nature translates into architecture. Erik Swyngedouw and Maria Kaïka in their article: "The Environment of the City...or the Urbanization of Nature", argue that the environment of the city results from the process of urbanization of nature. Society and nature are inseparable and their interactions "narrate many interrelated tales of the city" making the city a "palimpsest landscape" (2011: 569-571). The novel portrays the urban space of Miami as palimpsests of different environments: the built, the 'natural', the human and the verbal. The marine environment of Miami directly connected with the main setting of the novel - the Stiltsville enclave - is deeply affected by the hurricane. This dramatic event not only destroys the main built environment of the novel but also makes the characters change their lifestyle. The 'natural' environment has a binary depiction: idealized, mysterious, sentimental on one hand and dangerous, threatening, destructive and deadly on the other. The novel presents an idealized image of the human cityscape as people do not commit any violent acts except for the ones occurring during the McDuffie riots. The real danger is not created by humans but by nature, which poses a threat to the built and human aspects of the cityscape, including the special place of Stiltsville. The built environment translates into the human environment when the city landmark - Freedom Tower - is brought into the narrative to symbolize Cuban refugees. The verbal environment accompanies the 'natural' to emphasize the tropicality of the place. It also assists the depiction of the human environment by emphasizing the Hispanic presence in the city with the inclusion of Spanish-sounding names and the practice of dropping Spanish words into conversations.

Daniel's reflections demonstrate the sentimentality and selectivity characteristics of nostalgia. The characters identify with a place that is meaningful for them, one that both belongs to them and they belong to. John Sue states: "individuals can identify with mediated representations of place as well as the places themselves" (2005: 97). The narrator identifies with the place even when it disappears and she tries to retrieve it in two ways: by revoking past recollections and by developing the image of it. In both cases, Frances idealizes the home and depicts it with a great deal of sentimentality. Nostalgia and positive emotions are evoked again when she describes her 
husband: "He seemed to regard fatherhood and husbandhood the way a magician regards magic: the delight is in the mystery" (133). The narrator reconstructs the past in her storytelling, but the representation of the past is revisionary because only certain periods are selected for the reminiscence. Nostalgia is triggered by past recollections taking the form of shattered fragments of memory. The narrator allows us to enjoy the experience again and again; as cultural scholar Sean Scanlan puts it, "Nostalgia keeps on returning" (2004: 2). Frances keeps on returning to the stilt house which serves as an embodiment of her idealized past. The novel is about yearning for the figure and the place from the past that give meaning to the narrator's life, and it exemplifies the type of nostalgia that Svetlana Boym names 'reflective' as it stresses the meaning of emotions and social bonds that the characters develop in their lives in the place that is special for the narrator, the stilt house. Boym's concept of reflective nostalgia, which is linked with "individual and cultural memory", is present in the novel through the direct relationship between the writer's biography, the story's narrator and the storm-struck history of South Florida. The narrator's house no longer exists but the remaining structures of the Stiltsville community are the object of conservation activities. It is her heritage that she wishes to preserve; she cannot retrieve the past but she can keep recollections and create images.

The historical Stiltsville enclave is regarded as a living heritage of the past that is being preserved for the future. This magic landscape, which inspires historians, geographers, architects, and writers, may be destroyed by the tropical storms that are certain to hit Florida's shores in the future. If the state of Florida does not preserve and rebuild the stilt houses, those signature constructions which are part of Florida's cultural heritage will remain only in images and nostalgic memories.

\section{References}

Blij, H. de. 2009. The Power of Place: Geography, Destiny and Globalization's Rough Landscape. Oxford: Oxford University Press.

Boym, S. 2001. The Future of Nostalgia. New York: Basic Books.

Cook, P. 2005. Screening the Past: Memory and Nostalgia in Cinema. London/New York: Routledge. Daniel, S. 2010. Stiltsville. New York: HarperCollins Publishers.

Daniel, S. Biography webpage. 3 Mar. 2019. https://www.susannadaniel.com/bio

Davis, F. 1979. Yearning for Yesterday: A Sociology of Nostalgia. New York: Free Press.

Duyvendak, J. W. 2011. The Politics of Home: Belonging and Nostalgia in Western Europe and the United States. London: Palgrave Macmillan.

Eyman, S. 2010. A child of Miami's Stiltsville explores the precarious balance of marriage. Palm Beach Post (21 November 2010). https://www.palmbeachpost.com/entertainment/child-miamistiltsville-explores-the-precarious-balance-marriage/YjOuMx2zq5Jqk59Pb@Rq10/

Hutcheon, L. 2002. The Politics of Postmodernism. London/New York: Routledge.

Isenberg, A. 2004. Downtown America: A History of the place and the people who made it. Chicago/ London: The University of Chicago Press. 
Lowenthal, D. 2015. The Past Is a Foreign Country - Revisited. Cambridge/New York: Cambridge University Press.

Merriam Webster Dictionary online. (19 January 2019). https://www.merriam-webster.com/dictionary/Floridiana.

Rabin, C. 2017. Stiltsville still standing after Hurricane Irma's winds blew through. Miami Herald (21 September 2017). https://www.miamiherald.com/news/weather/hurricane/article174542451.html

Rubenstein, R. 2011. Home Matters: Longing and Belonging, Nostalgia and Mourning in Women's Fiction. New York: Palgrave Macmillan.

Sankovitch, N. 2011. Life's sturdy pilings: Stiltsville by Susanna Daniel. Huffington Post (25 May 2011). https://www.huffingtonpost.com/nina-sankovitch/lifes-sturdy-pilingsemst_b_675081.html?guccounter $=1$

Scanlan, S. 2004. Introduction: Nostalgia. Iowa Journal of Cultural Studies 5.1: 2-9.

Sedikides, C., Wildschut, T., Arndt, J. \& Routledge, C. 2008. Nostalgia. Past, present, and future. Current Directions in Psychological Science 17.5: 304-307.

Smith, K. K. 2000. Mere nostalgia. Notes on a progressive paratheory. Rhetoric \& Public Affairs 3.4: 505-527.

Sprengler, C. 2009. Screening Nostalgia. Populuxe props and Technicolor aesthetics in contemporary American film. New York/Oxford: Berghahn Books.

Stiltsville Trust. Seven remaining houses. http://stiltsvilletrust.org/pages/stiltsville_ remaining_houses.html

Sue, J. J. 2005. Ethics and Nostalgia in the Contemporary Novel. Cambridge/New York: Cambridge University Press.

Swyngedouw E. \& Kaïka, M. 2011. The environment of the city ... or the urbanization of nature. In: G. Bridge \& S. Watson (eds.), A Companion to the City, 567-580. Malden, MA, USA/Oxford, UK: Blackwell Publishing.

Tierney, J. 2013. What is nostalgia good for? Quite a bit, research shows. The New York Times (8 July 2013). https://www.nytimes.com/2013/07/09/science/what-is-nostalgia-good-forquite-a-bit-research-shows.html

Urry, J. 2003. City life and the senses. In: G. Bridge \& S. Watson (eds.), A Companion to the City, 388-397. Malden, MA, USA/Oxford, UK: Blackwell Publishing.

Valeri, L. A. 2011. A texture the facts can't convey: An interview with Susanna Daniel. Fiction Writers Review (28 March 2011). https://fictionwritersreview.com/interview/a-texturethe-facts-cant-convey-an-interview-with-susanna-daniel/

Wilson, J. L. 2005. Nostalgia. Sanctuary of Meaning. Cranbury, NJ: Rosemont Publishing.

Wirth-Nesher, H. 2001. Impartial maps: Reading and writing cities. In: R. Paddison (ed.), Handbook of Urban Studies, 52-66. Thousand Oaks, California: SAGE Publications.

Wright, G. 2008. USA: Modern Architectures in History. London, UK: Reaktion Books. 
Zukin, S. 1982. Loft Living: Culture and Capital in Urban Change. Baltimore, Maryland: The Johns Hopkins University Press.

\section{$* * *$}

Małgorzata Martynuska is an Associate Professor at the Institute of English Studies, University of Rzeszow, Poland. She is a graduate of American Studies Center at University of Warsaw (MA) and the Institute of American Studies and Polish Diaspora at Jagiellonian University in Cracow $(\mathrm{PhD})$. She completed her habilitation at SWPS University of Social Sciences and Humanities in Warsaw. Her scholarly interests focus on cultural hybridity of US Latinx, acculturation patterns, transculturation and ethnic representations in American popular culture. 